\title{
ANALISIS DAMPAK SEKTOR INDUSTRI MANUFAKTUR, KEMISKINAN DAN BELANJA PEMERINTAH BIDANG LINGKUNGAN TERHADAP KUALITAS AIR DI INDONESIA
}

\author{
Azanul Akbar Lubis \\ Mahasiswa Prodi Ilmu Ekonomi Pasca Sarjana Universitas Negeri Medan \\ Jl. Willem Iskandar Ps. V Medan Estate \\ Telepon. (061) 6636730, email: azak1988@gmail.com
}

\section{Zahari Zen \\ Fitrawaty}

Dosen Prodi Ilmu Ekonomi Pasca Sarjana Universitas Negeri Medan

Jl. Willem Iskandar Ps. V Medan Estate

Telepon. (061) 6636730, email:

zahari.zein@gmail.com\&ewahyunugrahadi@yahoo.com

\begin{abstract}
Manufacturing sector is one of the sectors that contribute to economic growth in Indonesia. Results of these contributions is the changing structure of the Indonesian economy from agriculture to the industrial sector. And poverty in Indonesia which is one indicator of well-being in an area tend to be in 2000 to 2010 has a pattern that tends to decline, although not very significant. Of 2 (two) variables, namely the Manufacturing Sector and Poverty, the author tries to determine the impact of variables on water quality in Indonesia, by adding variable Expenditures Environmental Affairs as variables that also impact the water quality in Indonesia. Manufacturing Sector GDP, the number of poor, Regional Budget (APBD) Environmental Field, each is used as a proxy for the manufacturing sector, poverty and Environment Sector Government expenditure. The data is compiled based on 28 provinces in Indonesia in 2009, 2010 and 2011. The results obtained showed that the industrial sector and poverty have a negative impact on water quality while Government Expenditure Environment Sector positive effect on water quality in Indonesia.
\end{abstract}

Keywords: Manufacturing IndustrySectors, Poverty, Environmental AffairsGovernment ExpenditureandWater QualityIndex

QE Journal | Vol.04 - No.02 June 2015 - 100 


\section{PENDAHULUAN}

ertumbuhan ekonomi merupakan salah satu indikator penting
guna mengukur tingkat kesejahteraan suatu masyarakat.
Pertumbuhan ekonomi tersebut dapat dilihat dan diukur dari efektifitas sektor-sektor yang ada. Sektor Industri Manufaktur merupakan salah satu sektor yang memberikan kontribusi yang cukup besar terhadap pertumbuhan ekonomi. Perubahan struktur ekonomi Indonesia, dalam waktu 25 tahun menggambarkan bahwa peran sektor industri terus mengalami peningkatan. Pada tahun 1985 sebesar 35,8\% meningkat menjadi $47 \%$ pada tahun 2010. Adapun sektor lainnya, seperti pertanian mengalami penurunan. Dimana pada tahun 1985 memberikan kontribusi sebesar 23,20\% dan pada tahun 2010 sebesar 15,3\% hal ini sebagaimana dapat dilihat pada Gambar 1.

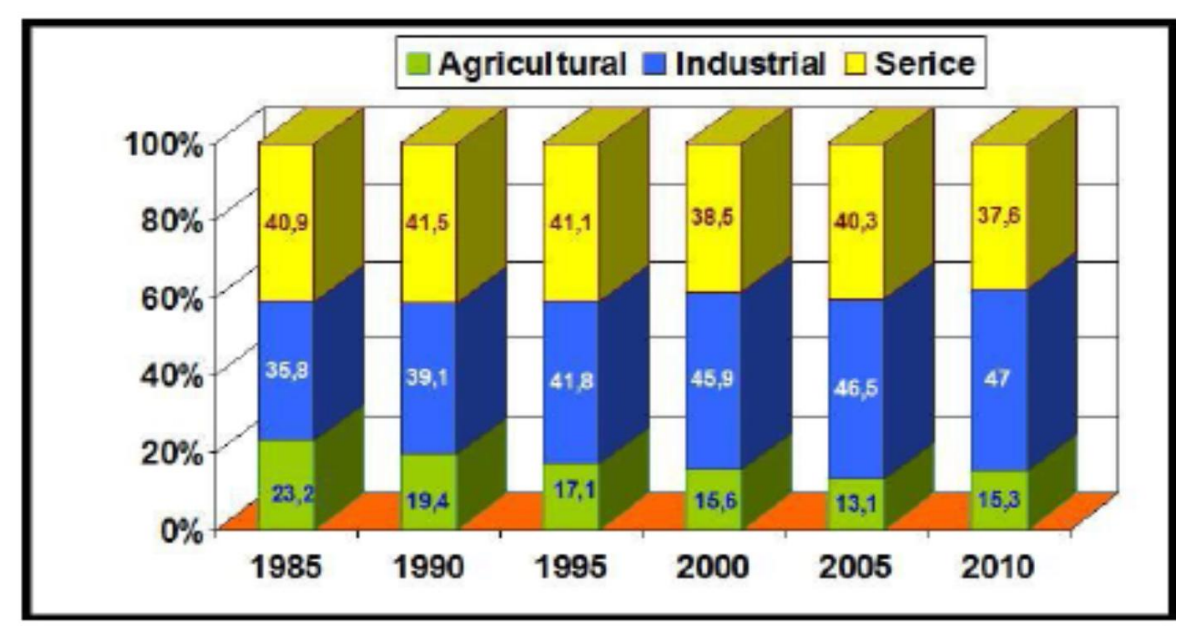

Sumber: Asian Development Bank (ADB), 2011

Gambar 1. Perubahan Struktur Ekonomi Indonesia(berdasarkan \% Sumbangan Terhadap GDP

Perubuhan struktur perekonomian ini, diduga juga memberikan dampak negatif terhadap kondisi lingkungan yang terdapat di sekitarnya, khususnya kualitas air sebagai sumber daya alam yang paling dibutuhkan untuk keberlangsungan makhluk hidup di bumi, sebagaimana diilustrasi pada Gambar 2. 


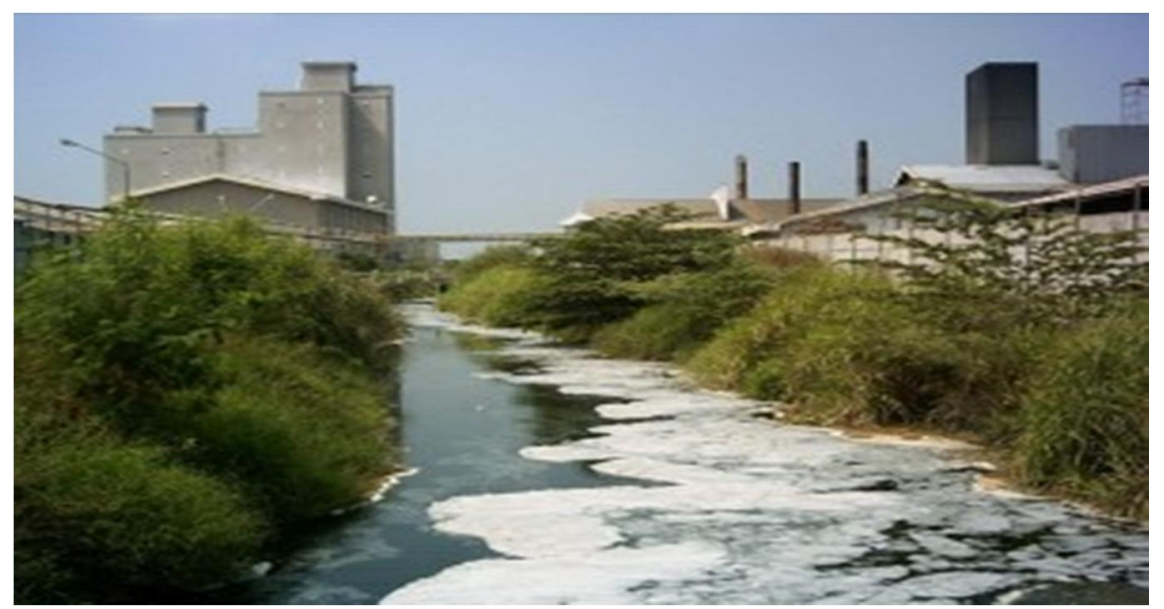

Sumber : Zen, 2012

Gambar 2. Kondisi Sungai Deli Yang Tercemar oleh Limbah Industri

Sebagaimana sektor industri manufaktur, kemiskinan juga merupakan indikator lain yang digunakan untuk mengukur tingkat kesejahteraan masyarakat. Semakin sedikit jumlah orang miskin di suatu daerah, maka semakin tinggi pula tingkat kesejahteraan pada daerah tersebut. Badan Pusat Statistik mencatat bahwa jumlah penduduk miskin di Indonesia mempunyai trenyang menurun dari tahun 2000 sampai dengan tahun 2010, sebagaimana terlihat pada Gambar 3.

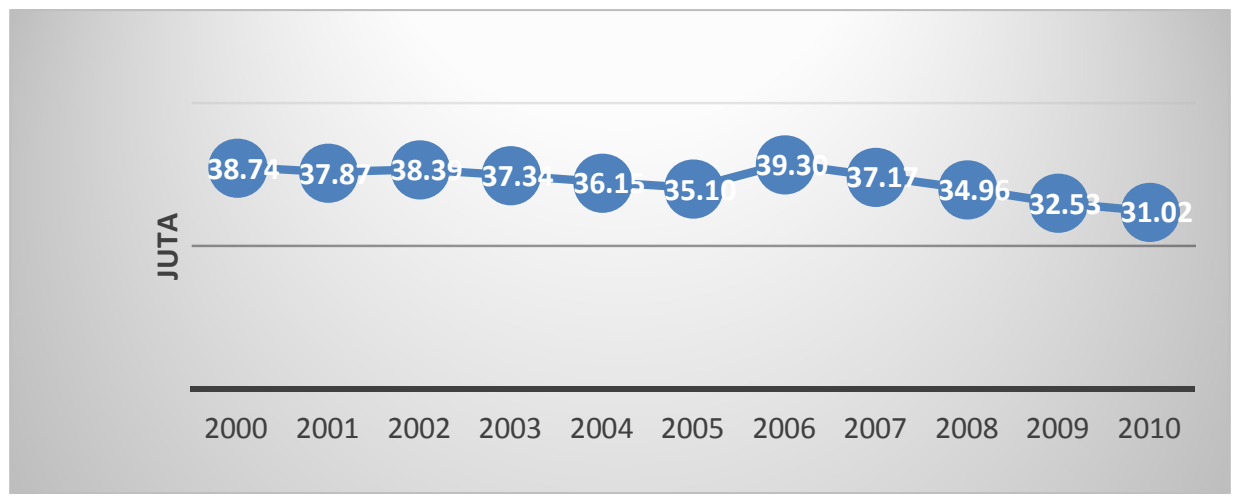

Sumber : Data diolah, 2015

Gambar 3. Perkembangan Jumlah Penduduk Miskin di Indonesia 
Hasil penelitian yang dilakukan oleh Dariah (2007), mengemukakan bahwa degradasi lingkungan pada lahan lebih ditentukan oleh kemiskinan, hal ini dikarenakan tekanan penduduk dalam hal pola tingkah laku dan kepeduliannya terhadap lingkungan sekitarnya. Hal serupa tentunya juga terjadi pada kualitas air. Kita melihat bahwa secara umum, penduduk miskin yang tinggal di kota-kota besar cenderung untuk memilih tinggal di pinggiran sungai. Hal ini tentunya juga memberikan tekanan yang cukup besar terhadap kualitas air sungai yang ada.

Pemerintah dalam hal ini hadir dan bertanggung jawab terhadap keberlangsung lingkungan hidup yang bersih, khususnya sumber daya air. Melalui kebijakan - kebijakan yang dikeluarkan diharapkan mampu untuk membentengi sumber daya air dari degradasinya. Berbagai kebijakan yang dikeluarkan oleh pemerintah diantaranya adalah regulasi dan belanja bidang lingkungan. Indonesia sebagaimana dirilis oleh Universitas Yale dan Universitas Columbia bekerja sama dengan Forum Ekonomi Dunia (World Economic Forum) kembali menerbitkan Indeks Kinerja Lingkungan Hidup (IKLH) dan Indeks Pengelolaan Lingkungan Hidup (IPLH)2012. Indonesia pada rilis tersebut menempati peringkat Indeks Kinerja Lingkungan Hidup ke 74 dan Indeks Pengelolaan Lingkungan Hidup ke 66 berada di bawah Malaysia, Brunei Darussalam, Thailan, Filiphina, Singapura, Kamboja dan Myanmar. Tentunya hal ini menggambarkan bahwa kualitas lingkungan hidup, khususnya kualitas airsebagai salah satu indikator kualitas lingkungan hidup di Indonesia masih lebih rendah jika dibandingkan negara-negara tersebut.Hal ini dapat dilihat dari Indeks Kualitas Air Indonesia pada tahun 2009 sebesar 45,2, tahun 2010 sebesar 48,85 dan tahun 2011 sebesar 46,63.

Berdasarkan data dan fakta di atas penulis akan melihat bagaimanakah "Analisi Dampak Sektor Industri Manufaktur, Kemiskinan dan Pengeluaran Pemerintah Bidang Lingkungan Terhadap Kualitas Air di Indonesia"

\section{METODE PENELITIAN}

Penelitian ini menggunakan data sekunder, yang meliputi: (1) Data PDB Sektor Industri Manufaktur (Sumber : BPS); (2) Data Kemiskinan (Sumber : BPS); (3) Data Belanja Pemerintah Bidang Lingkungan (Sumber: Kementerian Keuangan RI); (4) Indeks Kualitas Air (Sumber : Kementerian 
Lingkungan Hidup). Data yang digunakan adalah merupakan data panel rentang waktu antara tahun 2009-2011 dengan cross section 28 provinsi di Indonesia.

\section{Metode Analisis}

Analisis panel data pada penelitian ini menggunakan model Fixed Effect Model (FEM) dengan metode Fixed Effect Model Cross Section Weights dengan menggunakan software Eviews 6 untuk pengolahan data. Sebelum data diolah, penulis melakukan transforasi data ke dalam bentuk logaritma natural.Alat analisis ini mampu menjawab tujuan dari penelitian ini karena hasil penelitian ini akan memberikan hasil apakah PDB Sektor Industri Manufaktur, Kemiskinan berdampaknegatifdan Belanja Pemerintah Bidang Lingkungan berdampak positif terhadap Indeks Kualitas Air. Berdasarkan dasar pemikiran dan kerangka pemikiran yang telah diutarakan maka penelitian ini menggunakan spesifikasi model regresi sebagai berikut:

Keterangan:

$$
\mathrm{IKU}_{\mathrm{it}}=\beta_{0}+\beta_{1} \mathrm{YIM}_{i t}+\beta_{2} \mathrm{POV}_{\text {it }}+\beta_{3} \mathrm{FAL}_{\text {it }} \varepsilon_{\text {it }}
$$

IKA $A_{i t}=$ Indeks Kualitas Air untuk provinsi i pada tahun $\mathrm{t}$

YIMit = PDB Sektor Industri Manufaktur untuk provinsi i pada tahun $\mathrm{t}$

$\mathrm{POV}_{\text {it }}=$ Jumlah Penduduk Miskin untuk provinsi i pada tahun $\mathrm{t}$

FALit $=$ Fungsi Anggaraan Lingkungan Hidup untuk provinsi i pada tahun $\mathrm{t}$

$\varepsilon_{\text {it }} \quad=$ Gangguan stokastik

\section{HASIL DAN PEMBAHASAN}

\section{Deskripsi Variabel Penelitian}

Data PDB Sektor Industri Manufaktur, Kemiskinan, Belanja Pemerintah Bidang Lingkungan, dan Indeks Kualitas Air dapat dilihat pada tabel 1 (lampiran). Pada rentang waktu tahun 2009 sampai dengan 2011 rerata Indeks Kualitas Air tertinggi terdapat pada provinsi Sumatera Selatan sebesar 88,85. Dan rerata Indeks Kualitas Air terendah pada tahun penelitian terdapat pada provinsi Sulawesi Tenggara sebesar 8,47. PDB Sektor Industri Manufaktur Indonesia dari tahun 2009 hingga tahun 2011 mengalami peningkatan nilai. Provinsi Jawa Barat merupakan provinsi dengan PDB sektor industri manufaktur yang tertinggi secara rata-rata pada tahun penelitian yaitu sebesar Rp 126.947 Miliar, sedangkan provinsi 
Nusa Tenggara Timur merupakan provinsi dengan PDB sektor industri manufaktur yang terendah, yaitu sebesar Rp 183 miliar.

Secara umum krisis yang terjadi pada tahun 2008 tidak memberikan dampak buruk pada perekonomian Indonesia, namun terdapat beberapa Provinsi mengalami penurunan PDB Sektor Industri Manufaktur pada tahun 2009 s.d. 2011, diantaranya Provinsi Jawa Barat mengalami penurunan Rp 30.850 miliar pada tahun 2009 - 2010 dan Provinsi Kalimantan Timur mengalami penurunan sebesar Rp 713 miliar pada tahun 2009 - 2010 dan Rp 8.740 miliar pada tahun 2010 - 2011. Jika dilihat dari kontribusinya terhadap PDB Indonesia, pada tahun 2009 PDB sektor industri manufaktur memberikan sebesar 21,48 \%, tahun 2010 sebesar 21,01 $\%$, dan tahun 2011 sebesar $21,80 \%$.

Jumlah penduduk miskin secara keseluruhan di Indonesia mengalami penurunan pada tahun 2010, namun pada tahun 2011 jumlah pendudukan miskin di Indonesia bertambah. Provinsi dengan jumlah penduduk miskin rerata terbanyak pada tahun 2009 s.d. 2011 terdapat di provinsi Jawa Timur (5.636 ribu jiwa), Jawa Tengah (5.401 ribu jiwa) dan Jawa Barat (4.802 ribu jiwa). Sedangkan jumlah penduduk miskin terendah pada tahun penelitian terdapat pada provinsi Bangka Belitung (72 ribu jiwa) dan provinsi Kalimantan Tengah (159 ribu jiwa).

Belanja pemerintahbidang lingkungan Indonesia menurut provinsi dari tahun 2009 hingga tahun 2011 memiliki tren yang meningkat.Akan tetapi beberapa provinsi di Indonesia pada tahun penelitian, fungsi anggaran lingkungannya tidak mengikuti tren yang meningkat, diantaranya adalah provinsi Jawa Timur pada tahun 2009 memiliki anggaran lingkungan sebesar 1,649 triliun, pada tahun 2010 mengalami penurunan menjadi sebesar 1,223 triliun, dan pada tahun 2011 kembali mengalami penurunan menjadi sebesar 1,196 triliun. Provinsi Sulawesi Selatan pada tahun 2009 memiliki anggaran lingkungan sebesar 337 miliar, pada tahun 2010 mengalami penurunan menjadi sebesar 304 miliar, dan pada tahun 2011 kembali mengalami penurunan menjadi sebesar 271 miliar.

Dari data yang diperoleh didapati bahwa provinsi yang memiliki fungsi anggaran lingkungan terbesar adalah provinsi Jawa Timur dengan nilai anggaran 1,35 triliun rupiah, provinsi DKI dengan nilai anggaran lingkungan sebesar 1,24 triliun rupiah, dan provinsi Jawa Barat dengan 
nilai anggaran lingkungan sebesar 806 miliar rupiah. Sedangkan provinsi yang memiliki fungsi anggaran lingkungan terkecil adalah provinsi Maluku sebesar 59 miliar rupiah, provinsi Bengkulu dengan nilai fungsi anggaran lingkungan sebesar 62 miliar rupiah dan provinsi Yogyakarta dengan nilai fungsi anggaran lingkungan sebesar 67 miliar rupiah.

\section{Pembahasan}

Berikut pada tabel di bawah ini merupakan koefesian korelasi antara Indeks Kualitas Air dengan PDB Sektor Industri Manufaktur, Kemiskinan,dan Fungsi Anggaran Lingkungan.

Tabel 1. Hasil Korelasi Antara Indeks Kualitas Air dengan PDB Sektor Industri Manufaktur, Kemiskinan, dan Belanja Pemerintah Bidang Lingkungan di Indonesia

\begin{tabular}{cc}
\hline & IKA \\
\hline YIM & -0.271580 \\
POV & -0.140832 \\
FAL & -0.302658 \\
\hline
\end{tabular}

Sumber: Data diolah, 2015

Adapun hasil model regresi yang digunakan untuk mengukur dampak dari variabel PDB Industri Manufaktur, Kemiskinan, dan Belanja Pemerintah Bidang Lingkungan adalah sebagai berikut.

Tabel 2. Hasil Regresi Dampak YIM, POV, dan FAL Terhadap IKA

\begin{tabular}{cccccc}
\hline & Constant & YIM & POV & FAL & R-squared \\
\hline \multirow{2}{*}{ IKA } & 6.100973 & -0.261182 & -0.554442 & 0.264327 & 0.995254 \\
& $(0.0004)$ & $(0.0000)$ & $(0.0105)$ & $(0.0001)$ & \\
\hline
\end{tabular}

Sumber: Data diolah, 2015

Dari model yang digunakan, diperoleh F-statistic $=342.5191$ dengan nilai probability F-statistic 0,000000. Artinya model ini dapat diyakini pada alpha 5\%. Dalam model yang diestimasi, diperoleh nilai R-square 0.992348. Hal ini menunjukkan bahwa model yang diestimasi dapat menjelaskan variabel dependent (IKA) sebesar 99,23\% dan sisanya dipengaruhi oleh variabel lainnya.

Hasil analisis korelasi didapatkan koefisien korelasi antaraIndeks Kualitas Airdengan PDB Sektor Industri Manufaktur di Indonesiaadalah sebesar 0,27158. Koefisien tersebut mengartikan bahwa Indeks Kualitas 
Airmemiliki hubungan asosiasi negatif dengan PDB Sektor Industri Manufaktur. Sedangkan dalam model regresi yang digunakan nilai koefisien PDB Sektor Industri Manufaktur adalah -0.261182 dengan nilai probability 0,0004.Hasil regresi ini juga menjelaskan bahwa jika PDB sektor industri manufaktur meningkat 1 persen maka berdampak pada Indeks Kualitas Air turun sebesar 0,261182 persen. Dari sisi kesesuaian dengan teori "limits to growth" arah hubungannya menunjukkan bahwa peningkatan PDB Sektor Industri Manufaktur diikuti dan/atau memberikan dampak negatif terhadap Indeks Kualitas Air. Dan berdasarkan teori Environmental Kuznets Curev menjelaskan bahwa peningkatan PDB Sektor Industri Manufaktur di Indonesia berada pada tahap awal, yaitu tahap pada saat pencemaran lingkungan cenderung meningkat. Hal ini terjadi karena peningkatan produksi industri manufaktur akan memerlukan pemakaian bahan bakar minyak yang lebih besar dan juga menghasilkan residu / sisa hasil produksi (limbah pabrik cair) yang lebih banyak pula. Proses produksi yang diasumsikan penulis tidak ramah terhadap lingkungan ini akan mengakibatkan menurunkan kualitas air sungai maupun air tanah yang terdapat di sekitarnya.

Teori limits to growth dalam hal ini terbukti, sumber daya alam yang dapat diperbaharui sekalipun (SDA renewable), yaitu air juga memiliki batas carying capacity, yang menyebabkan degradasi kualitas air. Hal ini karena aktifitas industri yang secara terus menerus dan dalam kapasitas besar membutuhkan bahan input yang berasal dari sumber daya alam yang beras. Eksploitasi sumber daya alam yang dilakukan secara terus menerus, misalnya terhadap hutan, melalui penebangan hutan akan mengurangi kemampuan hutan sebagai sebagai sumber air tanah. Terlebih lagi marginal external cost dari proses produksi dan konsumsi barang yang dihasilkan tidak diinternalisasikan kedalam harga barang tersebut. Sehingga tidak ada yang bertanggung jawab secara penuh dalam menetralisir dan/atau mengelola limbah yang dihasilkan.

Koefesien korelasi yang didapatkan koefisien korelasi antara Indeks Kualitas Air dengan Kemiskinandi Indonesiaadalah sebesar -0.140832. Koefisien tersebut mengartikan bahwa Indeks Kualitas Air memiliki hubungan asosiasi negatif dengan Kemiskinan. Sedangkan dalam model regresi yang digunakan nilai koefisien Kemiskinan adalah -0.554442 dengan nilai probability 0.0105 . Hasil regresi ini juga menjelaskan bahwa 
jika Kemiskinan meningkat 1 persen maka berdampak pada Indeks Kualitas Air turun sebesar 0.554442 persen. Adapun dari sisi kesesuaian dengan teori "limits to growth" arah hubungannya menunjukkan bahwa peningkatan jumlah orang miskin diikuti dan/atau memberikan dampak negatif terhadap Indeks Kualitas Air. Masyarakat miskin yang tidak memiliki ketidakmampuan individu dalam memenuhi kebutuhan dasar minimal untuk hidup layak tentunya merasa berat dan tidak mempunyai kemampuan juga dalam melakukan upaya guna perbaikan kualitas lingkungan. Herdiani (2009), faktor-faktor yang secara nyata mempengaruhi kesediaan atau ketidaksediaan masyarakat membayar perbaikan lingkungan yaitu pendapatan, luas tempat tinggal, dan status tempat tinggal. Dan faktor pendapatan merupakan salah satu indikator dalam pengukuran kemiskinan. Sehingga dapat dijelaskan bahwa semakin rendah pendapatan seseorang, maka sesorang tersebut semakin miskin tingkat kemiskinannya sehingga semakin rendah kesediaan masyarakat untuk mengeluarkan biaya guna pengelolaan lingkungan hidup, termasuk kualitas air.

Koefesien korelasi yang didapatkan koefisien korelasi antara Indeks Kualitas Air dengan Belanja Pemerintah Bidang Lingkungan di Indonesiaadalah -0.302658 . Koefisien tersebut mengartikan bahwa Indeks Kualitas Air memiliki hubungan asosiasi negatif denganBelanja Pemerintah Bidang Lingkungan. Adapun dalam model regresi yang digunakan nilai koefisien Belanja Pemerintah Bidang Lingkungan adalah 0.264327 dengan nilai probability 0,0001. Hasil regresi ini juga menjelaskan bahwa jika Belanja Pemerintah Bidang Lingkungan meningkat 1 persen maka berdampak pada peningkatan Indeks Kualitas Air sebesar 0.264327 persen. Adapun dari sisi kesesuaian dengan teori "limits to growth" arah hubungannya menunjukkan bahwa peningkatan jumlah orang miskin diikuti dan/atau memberikan dampak negatif terhadap Indeks Kualitas Air.

Dampak variabel FAL positif dan signifikan pada tingkat kepercayaan 90 persen. Terbukti bahwa Fungsi Anggaran Lingkungan berdampak positif dan signifikan terhadap Indeks Kualitas Air di Indonesia. Hal ini menunjukkan bahwa belanja lingkungan yang dikeluarkan oleh pemerintah untuk menjaga kelestarian lingkungan hidup, khususnya kualitas air, efektif dan optimal dalam pengelolaan, penggunaan, dan 
pemanfaatannya guna mendukung dan menjaga kualitas air di Indonesia. Hal ini mendukung penelitian yang dilakukan Sitepu (2007), dimana pada hasil penelitiannya menunjukkan anggaran lingkungan berpengaruh negatif terhadap penurunan kualitas lingkungan. Dan pemerintah harus mengambil peran utama guna menjaga keberlangsungan pertumbuhan ekonomu yang sejalan kelestarian lingkungan melalui fungsi anggarannya. Angka probability t-statistic FAL pada model yang signifikan mendukung teori ekonomi yang tidak menyerahkan seluruh aktifitas perekonomian kepada pasar, akan tetapi pemerintah harus terus melakukan campur tangan / intervensi pada pasar untuk mencapai titik keseimbangan (MSB = MSC) sehingga tidak tejadinya eksternalitas negatif terhadap lingkungan.

\section{SIMPULAN DAN SARAN}

\section{Simpulan}

Dari koefesien korelasi dan hasil estimasi model yang digunakan menunjukan bahwa PDB Sektor Industri Manufaktur dan Kemiskinan berdampak negatif sedangkan Belanja Pemerintah Bidang Lingkungan berdampak positif terhadap kualitas air, yang dalam penelitian ini diproksikan dengan Indeks Kualitas Air.

\section{Saran}

Pemerintah diharapkan lebih meningkatkan pengawasan dan mengeluarkan kebijakan yang mendukung terciptanya pertumbuhan ekonomi dan peningkatan pendapatan masyarakat guna terciptanya kualitas lingkungan hidup, khususnya air yang berkualitas, serta terbatasinya dengan lebih ketat sektor-sektor yang memberikan dampak negatif terhadap lingkungan hidup dan meningkatkan porsi belanja pemerintah bidang lingkungan.

\section{DAFTAR PUSTAKA}

Ahmad Fauzi. 2010. Ekonomi Sumber Daya Alam dan Lingkungan Teori dan Aplikasi. PT. Gramedia Pustaka Utama.x

Anonim. 2011. Undang Undang No. 23 Tahun 1997 Tentang : Pengelolaan Lingkungan Hidup. Kementrian Lingkungan Hidup Republik 
Indonesia.http://landspatial.bappenas.go. id/peraturan/the_file/UU2397.pdf. Diakses tanggal 26 juni pukul 16.06 WIB

Arsyad, Lincoln. 1999. Ekonomi Pembangunan. Edisi Keempat. STIE YKPN Yogyakarta

Barros, Fabio, et. al. 2002. Poverty and Environmental Degradation : the Kuznets Environmental Curve for the Brazilian Case.

Dornbusch R, Fischer S, Startz R. 2004. Macroeconomics $8^{\text {th }}$ Edition. New York : Mc Graw-Hill.

Gujarati, D. 1997. Ekonometrika Dasar. Erlangga, Jakarta.

Gujarati, D ; Porter, Dawn C. 2009. Basic Econometrics. 5th edition, McGraw Hills.

Hyun-Hoon Lee, Rae Kwon Chung, Chung Mo Koo. 2005. On the Relationship between Economic Growth and Environmental Sustainability.

Hutabarat, L. 2010. Pengaruh PDRB Sektor Industri Terhadap Kualitas Lingkungan Ditinjau Dari Emisi Sulfur dan CO2 di Lima Negara Anggota Asean Periode 1980-2000.Skripsi Fakultas Ekonomi Universitas Diponegoro.

Idris, 2010. Environmental Kuznets Curve: Bukti Empiris Hubungan antara Pertumbuhan Ekonomi dan Kualitas Lingkungan di Indonesia. Fakultas Ekonomi Universitas Negeri Padang.

Jaekyu, Lim. 1997. Economic Growth and Environment: Some Emperical Evidences From South Korea.

Mankiw, N.Gregory. 2000. Teori Makro Ekonomi.Ed.4. PT. Erlangga. Jakarta.

Min, D K. 2003. Environmental Condition and Govermental Fiscal Policy. Social Indicators Research, 62 (1) : 321

Nopirin, 2000. Pengantar Ilmu Ekonomi Makro dan Mikro. Edisi Pertama. Balai Pustaka Fakultas Ekonomi. Yogyakarta.

Panayotou, T. 2003. Economic Growth and The Environment. Harvard University and Cyprus International Institute of Management 